\title{
Ethics, Integrity, and Retributions of Digital Detection Surveillance Systems for Infectious Diseases: Systematic Literature Review
}

Ivy Y Zhao ${ }^{1^{*}}$, PhD; Ye Xuan Ma²*, MA; Man Wai Cecilia Yu², MBBS; Jia Liu ${ }^{3}$ PhD; Wei Nan Dong², PhD; Qin Pang $^{4}$, MSc; Xiao Qin Lu ${ }^{5}$, MM; Alex Molassiotis ${ }^{1}$, PhD; Eleanor Holroyd ${ }^{6}, \mathrm{PhD}$; Chi Wai William Wong ${ }^{2,7}, \mathrm{PhD}$

${ }^{1}$ WHO Collaborating Centre for Community Health Services, School of Nursing, The Hong Kong Polytechnic University, Hong Kong SAR, China

${ }^{2}$ Department of Family Medicine and Primary Care, Li Ka Shing Faculty of Medicine, The University of Hong Kong, Hong Kong SAR, China

${ }^{3}$ Shenzhen Institute of Advanced Technology, Chinese Academy of Sciences, Shenzhen, China

${ }^{4}$ Department of Information Technology, University of Hong Kong-Shenzhen Hospital, Shenzhen, China

${ }^{5}$ School of General Practice and Continuing Education, Capital Medical University, Beijing, China

${ }^{6}$ School of Clinical Sciences, Auckland University of Technology, Auckland, New Zealand

${ }^{7}$ Department of Family Medicine and Primary Care, University of Hong Kong-Shenzhen Hospital, Shenzhen, China

*these authors contributed equally

Corresponding Author:

Chi Wai William Wong, PhD

Department of Family Medicine and Primary Care

Li Ka Shing Faculty of Medicine

The University of Hong Kong

3/F, Ap Lei Chau Clinic

161 Main Street, Ap Lei Chau

Hong Kong SAR

China

Phone: 8625185657

Email:wongwcw@hku.hk

\section{Abstract}

Background: The COVID-19 pandemic has increased the importance of the deployment of digital detection surveillance systems to support early warning and monitoring of infectious diseases. These opportunities create a "double-edge sword," as the ethical governance of such approaches often lags behind technological achievements.

Objective: The aim was to investigate ethical issues identified from utilizing artificial intelligence-augmented surveillance or early warning systems to monitor and detect common or novel infectious disease outbreaks.

Methods: In a number of databases, we searched relevant articles that addressed ethical issues of using artificial intelligence, digital surveillance systems, early warning systems, and/or big data analytics technology for detecting, monitoring, or tracing infectious diseases according to PRISMA (Preferred Reporting Items for Systematic Reviews and Meta-Analyses) guidelines, and further identified and analyzed them with a theoretical framework.

Results: This systematic review identified 29 articles presented in 6 major themes clustered under individual, organizational, and societal levels, including awareness of implementing digital surveillance, digital integrity, trust, privacy and confidentiality, civil rights, and governance. While these measures were understandable during a pandemic, the public had concerns about receiving inadequate information; unclear governance frameworks; and lack of privacy protection, data integrity, and autonomy when utilizing infectious disease digital surveillance. The barriers to engagement could widen existing health care disparities or digital divides by underrepresenting vulnerable and at-risk populations, and patients' highly sensitive data, such as their movements and contacts, could be exposed to outside sources, impinging significantly upon basic human and civil rights.

Conclusions: Our findings inform ethical considerations for service delivery models for medical practitioners and policymakers involved in the use of digital surveillance for infectious disease spread, and provide a basis for a global governance structure.

Trial Registration: PROSPERO CRD42021259180; https://www.crd.york.ac.uk/prospero/display_record.php?RecordID=259180

(J Med Internet Res 2021;23(10):e32328) doi: $\underline{10.2196 / 32328}$ 


\section{KEYWORDS}

artificial intelligence; electronic medical records; ethics; infectious diseases; machine learning

\section{Introduction}

In the wake of the global COVID-19 outbreak, there is growing pressure to improve our existing practice in the prevention and ongoing monitoring of emerging infectious diseases and the adoption of targeted interventions for emerging infectious diseases. Current infectious disease surveillance systems in most countries are remarkably similar. Once a case is clinically suspected and confirmed, there are multiple levels of reporting [1]. Then, the accumulated information from local institutions is aggregated, processed, and defined at the population level before actions are subsequently disseminated through the system from a "top-down" approach. The existing process carries an inevitable time lag that can result in both reduced effectiveness for responsive public health interventions [2] and opportunities for doctors and patients to negotiate reporting, which can have catastrophic results, as had been observed in the early COVID-19 outbreak in China [3] and the Ebola outbreak in West Africa [4]. The need for timely data collection or sharing, processing, decision making, and reporting in infectious disease surveillance has been identified as one of the main drivers for introducing artificial intelligence (AI) technology.

With the establishment of electronic health records (EHRs), big data have been acquired, making it possible to build data-intensive infectious disease surveillance or early warning systems, pre-empt emergency response, and strengthen infection prevention and control. Machine learning (ML) technologies, a multiplying form of AI, has shown considerable potential in tracing the source and detecting potential outbreaks or novel infectious diseases using patients' EHRs. By utilizing real-time digital data analysis, a fully automated system could be built to transmit, through extraction, structured data and doctors' medical records in text, while new technologies, such as named entity recognition, would allow extraction of patient-related features from the unstructured text into predefined categories to support future infectious disease monitoring and surveillance [5]. Examples of enhanced timeliness resulting from this approach in COVID-19 case tracing have been reported in China and several other Asian counties [3]. When AI is being employed for infectious disease control (eg, using mobile phone apps to trace COVID-19 cases), potentially infected patients, their close contacts, and, at times, larger communities can be tracked, tested, and, if necessary, quarantined to prevent further outbreaks.

Nonetheless, the advantages of big data and ML in infectious disease control need to be weighed against the considerable ethical and legal concerns pertaining to the protections and privacy of individuals and the public in respect to access, use, and sharing of large data sets of patients' medical records. These kinds of AI interventions raise complex contemporary ethical questions regarding potential misuse of personal information and informed consent that have the potential to infringe on one's human and civil rights. Furthermore, there is the heightened risk of patients' personal information being leaked to social media when they have previously been assured of confidentiality and privacy [6]. Reidentification of named patients is a major concern when databases are hacked [7], and data custodians may sell data for financial gain to pharmaceutical, insurance, or software companies [8]. Furthermore, the routine use of big data analytics (BDA) or the ethics and widespread moral implications of ML continue to be vigorously debated around the accuracy of reporting $[9,10]$, and the consequences of inaccuracies in the reporting of outbreaks are gaining considerable attention [11]. These developments, often in rapid response situations, have sparked issues between optimizing population health outcomes informed by epidemiology and public health, and societal or individual ethical rights and protections that inform human rights and freedom of choice.

Notwithstanding these debates, BDA is critical for managing communicable disease spread or outbreaks in today's digital world where consistency in the application of regulations or rules of privacy, confidentiality, transparency, data handling, and security safeguards for ML transmission required to protect individuals' rights is limited [12]. This study set out to examine the ethical issues of using AI and identify an intersection or balance between the protection of individuals' human rights and patients' autonomy, and common good for population-based public health outcomes specific to infectious disease control and prevention with the aim of investigating ethical issues identified from utilizing AI-augmented surveillance or early warning systems to monitor and detect common or novel infectious disease outbreaks.

\section{Methods}

\section{Search Strategy and Selection Criteria}

We searched broad search engines with no time restriction. CINAHL, PubMed, Science Direct, MEDLINE, Google Scholar, and Scopus, as well as legal and sociological databases were searched from database inception to December 8, 2020. Additionally, relevant articles from the documents' bibliography and from other articles that cited the documents were retrieved. The following search terms and combination of terms were utilized: ethic* OR "data security" OR "data privacy" OR sensitiv* OR confidential* OR anonym* OR "personally identifiable information" OR privacy or "human right*" AND "electronic health records" OR ehr OR "Clinical decision support system" OR cdss OR "Artificial Intelligence" OR ai OR "augmented surveillance" OR surveillance OR "contact tracing" OR "Machine Learning" OR ml OR "deep learning" AND "Infectious Disease" OR “Communicable Diseases." Prior to the searches, the authors reviewed all search terms. In order to identify all existing literature for this review, we considered all peer-reviewed empirical research articles, review reports, and grey reports. To enhance the rigor of the review, our approach followed the PRISMA (Preferred Reporting Items for Systematic Reviews and Meta-Analyses) guidelines (Multimedia Appendix 1) [13]. 


\section{Inclusion and Exclusion Criteria}

There were no language restrictions placed on the literature search. To be included for further review, the collected articles must have addressed the ethical issues of using AI, digital surveillance systems, early warning systems, and/or BDA technology for detecting, monitoring, or tracing specifically infectious diseases.

\section{Literature Selection}

We selected literature for inclusion in 2 stages to ensure rigor. In the first stage, 2 authors (IYZ and YXM) independently screened the titles and abstracts of all citations for potentially relevant articles. In the second stage, the same 2 authors independently examined the full texts of these papers against prespecified inclusion criteria. Any discrepancies were resolved with input from a third author (EH). Of the 6714 titles and abstracts reviewed, we excluded 6668 articles that did not meet our eligibility criteria, resulting in 46 articles for full-text review. Additionally, 17 articles were excluded because they (1) were not related to digital surveillance systems, (2) did not focus on infectious diseases, or (3) lacked focus on ethical concerns. In all, 29 papers satisfied our eligibility criteria and were included by consensus agreement (Figure 1).

Figure 1. PRISMA (Preferred Reporting Items for Systematic Reviews and Meta-Analyses) flowchart of the literature review.

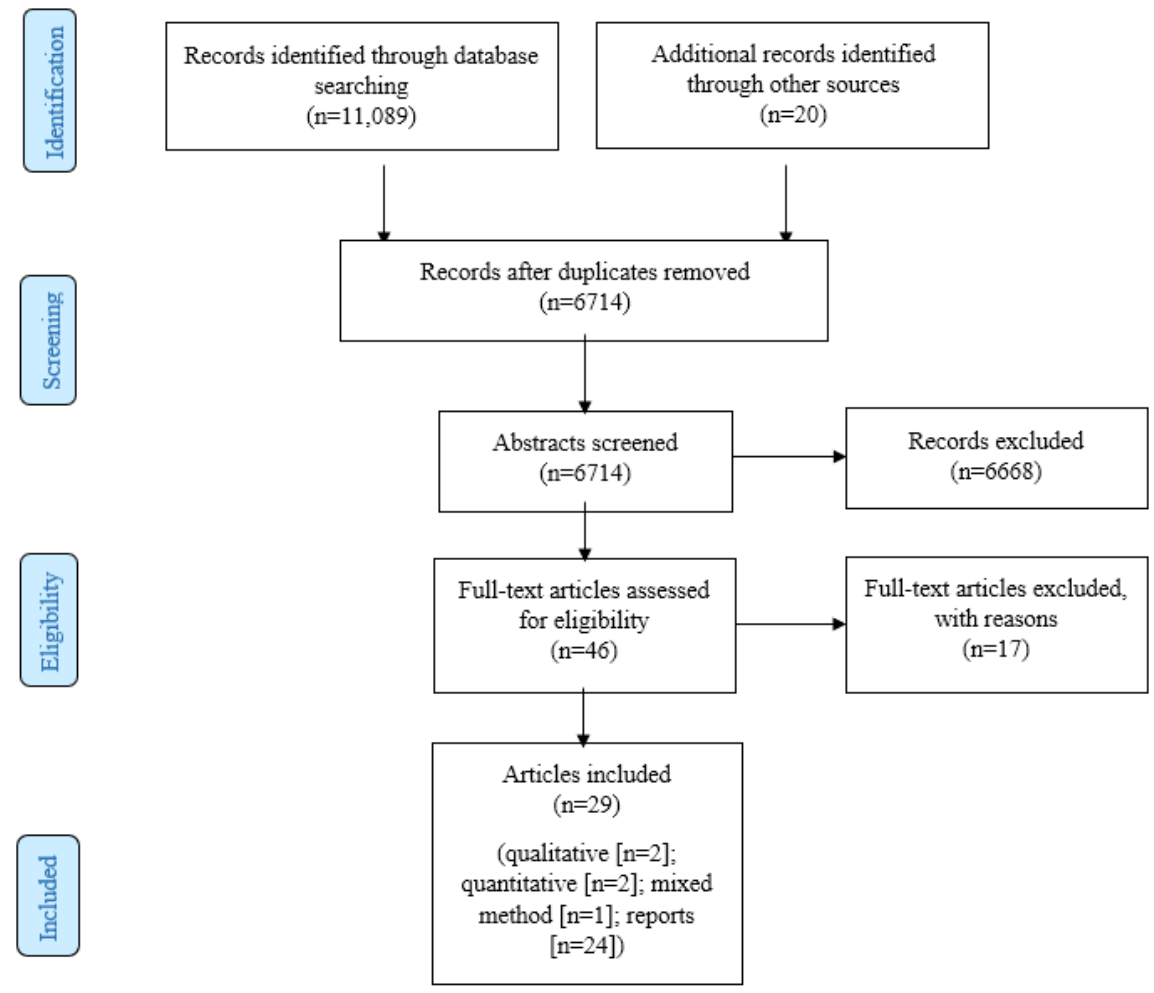

\section{Data Extraction, Quality Assessment, and Data Analysis}

All authors read and reviewed the 29 articles in order to summarize the approaches, methodologies, samples, and findings. Two authors (IYZ and YXM) undertook literature quality assessment, extracted data from the literature, included them into a spreadsheet, and analyzed the data independently. Discrepancies were resolved, and data were confirmed in several rounds of discussions with other team members. We evaluated study quality and methodological rigor for 5 empirical studies by using the modified mixed-methods appraisal tool (MMAT) [14], which was not applicable for the remaining discussion papers. Lower quality scores did not result in exclusion of any articles. However, the findings of articles with lower quality scores were given less weight during data analysis.

We structured our identified ethical issues using a theoretical framework developed by Asadi et al [15], in which key concepts of prior BDA had been identified, defined, and examined using stakeholder theory and discourse ethics [16]. Key themes from our review were discussed and summarized, and the gaps in the literature and methodologies were identified.

\section{Results}

\section{Overview and Participant Demographics}

Among the 29 included articles, 2 qualitative studies [17,18], 2 quantitative studies [19,20], 1 mixed methods study [21], and 24 discussion papers were identified (Table 1). All of the selected articles were published between the years 2015 and 2021. The 5 empirical studies [17-21] adopted a combination of focus groups, a Delphi approach, a database digital ethnography, and surveys as research methods, and they were all identified as high quality. Together they included 7331 participants. Of these 5 studies, 1 was conducted in South Korea [21] and 4 in Australia [17,19-21]. Four studies [17-19,21] reported gender ratios and $3[17,19,21]$ demonstrated age ranges. Research participants were the general public; policymakers; and experts in infectious diseases, epidemiology, food safety, health informatics systems, and health and technology law. 
Table 1. Summary of ethical issues identified from utilizing digital surveillance systems for infectious diseases.

\begin{tabular}{|c|c|c|c|c|c|c|c|}
\hline $\begin{array}{l}\text { Article type, and } \\
\text { authors and year }\end{array}$ & Country & Journal & $\begin{array}{l}\text { 1. Sampling } \\
\text { frame } \\
\text { 2. Sample size } \\
\text { 3. Age } \\
\text { 4. Gender ratio } \\
\text { (F:M) } \\
\text { 5. Sampling } \\
\text { method }\end{array}$ & Study aim & $\begin{array}{l}\text { Context of } \\
\text { studies }\end{array}$ & $\begin{array}{l}\text { Methodology } \\
\text { and methods }\end{array}$ & $\begin{array}{l}\text { Key and relevant } \\
\text { findings }\end{array}$ \\
\hline \multicolumn{8}{|l|}{$\begin{array}{l}\text { Journal articles } \\
(n=5)\end{array}$} \\
\hline $\begin{array}{l}\text { Degeling et al } \\
\text { (2020) [17] }\end{array}$ & Australia & $\begin{array}{l}\text { BMC Medical } \\
\text { Ethics }\end{array}$ & $\begin{array}{l}\text { 1. People who } \\
\text { had previously } \\
\text { volunteered to } \\
\text { take part in re- } \\
\text { search and top- } \\
\text { ic-blinded so- } \\
\text { cial media ad- } \\
\text { vertising on } \\
\text { Facebook } \\
\text { 2. } \mathrm{n}=50 \\
\text { 3. } 18-34 \text { y } \\
(\mathrm{n}=15) ; 35-54 \text { y } \\
(\mathrm{n}=22) ; \text { and }>55 \\
\mathrm{y}(\mathrm{n}=11) \\
\text { 4. } 27: 21 \\
\text { 5. Random sam- } \\
\text { pling }\end{array}$ & $\begin{array}{l}\text { Examine the pub- } \\
\text { lic acceptability } \\
\text { and ethical con- } \\
\text { cerns of commu- } \\
\text { nity juries on inte- } \\
\text { gration of big da- } \\
\text { ta analytics } \\
\text { (BDA) into com- } \\
\text { municable dis- } \\
\text { ease control }\end{array}$ & $\begin{array}{l}\text { BDA was per- } \\
\text { ceived as intru- } \\
\text { sive and a threat } \\
\text { to privacy. }\end{array}$ & $\begin{array}{l}\text { Qualitative; } \\
\text { deliberative } \\
\text { group ses- } \\
\text { sions; Delphi } \\
\text { study ap- } \\
\text { proach }\end{array}$ & $\begin{array}{l}\text { Almost all jurors } \\
\text { supported data link- } \\
\text { age for public health } \\
\text { research and suggest- } \\
\text { ed deidentification } \\
\text { practices. Three ju- } \\
\text { ries raised several } \\
\text { conditions related to } \\
\text { system oversight and } \\
\text { security being met. } \\
\text { One concern was } \\
\text { about loss of privacy } \\
\text { and mistrust in gov- } \\
\text { ernments to run se- } \\
\text { cure and effective } \\
\text { systems. }\end{array}$ \\
\hline $\begin{array}{l}\text { Kim et al (2021) } \\
{[18]}\end{array}$ & Korea & $\begin{array}{l}\text { Social Science } \\
\& \text { Medicine }\end{array}$ & $\begin{array}{l}\text { 1. Comments } \\
\text { from January to } \\
\text { May } 2020 \text { made } \\
\text { by Korean } \\
\text { mothers on } 15 \\
\text { internet groups } \\
\text { called "mom } \\
\text { cafes" } \\
\text { 2. n=3729 } \\
\text { 3. N/A }{ }^{\mathrm{a}} \\
\text { 4. Female } \\
\text { 5. Purposive } \\
\text { sampling }\end{array}$ & $\begin{array}{l}\text { Examine how } \\
\text { Korean mothers } \\
\text { understand } \\
\text { morality in the } \\
\text { context of } \\
\text { COVID-19 con- } \\
\text { tact-tracing } \\
\text { surveillance }\end{array}$ & $\begin{array}{l}\text { Korean mothers } \\
\text { uploaded } \\
\text { COVID-19 pa- } \\
\text { tient information } \\
\text { on the boards of } \\
\text { online groups for } \\
\text { discussion. }\end{array}$ & $\begin{array}{l}\text { Qualitative; } \\
\text { database digi- } \\
\text { tal ethnogra- } \\
\text { phy; reflexive } \\
\text { thematic analy- } \\
\text { sis }\end{array}$ & $\begin{array}{l}\text { Nonmaleficence is } \\
\text { the core morality } \\
\text { considered by Kore- } \\
\text { an mothers. }\end{array}$ \\
\hline $\begin{array}{l}\text { Degeling et al } \\
\text { (2020) [19] }\end{array}$ & Australia & BMJ Open & $\begin{array}{l}\text { 1. The Aus- } \\
\text { tralian general } \\
\text { population } \\
\text { 2. } \mathrm{n}=2008 \\
\text { 3. Median } 46 \mathrm{y} \\
(18-89 \mathrm{y}) \\
\text { 4. } 1015: 993 \\
\text { 5. Purposive } \\
\text { sampling }\end{array}$ & $\begin{array}{l}\text { Compare the val- } \\
\text { ue of core } \\
\text { surveillance sys- } \\
\text { tem attributes to } \\
\text { the Australian } \\
\text { public before and } \\
\text { during the early } \\
\text { stages of the } \\
\text { COVID-19 pan- } \\
\text { demic }\end{array}$ & $\begin{array}{l}\text { New technology } \\
\text { raised concerns } \\
\text { of privacy disclo- } \\
\text { sure and misuse } \\
\text { in the COVID-19 } \\
\text { outbreak. }\end{array}$ & $\begin{array}{l}\text { Quantitative; } \\
\text { online survey }\end{array}$ & $\begin{array}{l}\text { After the COVID-19 } \\
\text { pandemic, partici- } \\
\text { pants demonstrated } \\
\text { greater preference } \\
\text { for a high data secu- } \\
\text { rity surveillance sys- } \\
\text { tem for public } \\
\text { health. }\end{array}$ \\
\hline
\end{tabular}




\begin{tabular}{|c|c|c|c|c|c|c|c|}
\hline $\begin{array}{l}\text { Article type, and } \\
\text { authors and year }\end{array}$ & Country & Journal & $\begin{array}{l}\text { 1. Sampling } \\
\text { frame } \\
\text { 2. Sample size } \\
\text { 3. Age } \\
\text { 4. Gender ratio } \\
\text { (F:M) } \\
\text { 5. Sampling } \\
\text { method }\end{array}$ & Study aim & $\begin{array}{l}\text { Context of } \\
\text { studies }\end{array}$ & $\begin{array}{l}\text { Methodology } \\
\text { and methods }\end{array}$ & $\begin{array}{l}\text { Key and relevant } \\
\text { findings }\end{array}$ \\
\hline $\begin{array}{l}\text { Thomas et al } \\
(2020)[20]\end{array}$ & Australia & $\begin{array}{l}\text { JMIR Public } \\
\text { Health Surveil- } \\
\text { lance }\end{array}$ & 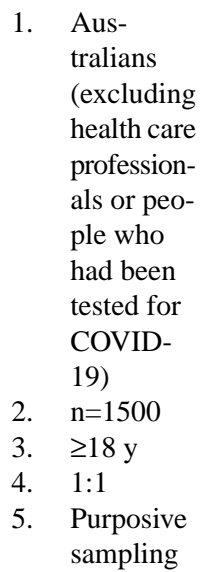 & $\begin{array}{l}\text { Investigate the } \\
\text { ethical issues of } \\
\text { adopting the Aus- } \\
\text { tralian govern- } \\
\text { ment's COVID } \\
\text { safe app }\end{array}$ & $\begin{array}{l}\text { App-based con- } \\
\text { tact tracing for } \\
\text { curbing the trans- } \\
\text { mission of } \\
\text { COVID-19 needs } \\
\text { widespread adop- } \\
\text { tion. }\end{array}$ & $\begin{array}{l}\text { Quantitative; } \\
\text { online nation- } \\
\text { al survey }\end{array}$ & $\begin{array}{l}\text { Privacy, data stor- } \\
\text { age, and technical } \\
\text { functions are ethical } \\
\text { issues that hinder } \\
\text { contact-tracking } \\
\text { apps. }\end{array}$ \\
\hline $\begin{array}{l}\text { Degeling et al } \\
(2019)[21]\end{array}$ & Australia & $\begin{array}{l}\text { Health Re- } \\
\text { search Policy } \\
\text { and Systems }\end{array}$ & $\begin{array}{l}\text { 1. Australian- } \\
\text { based policy } \\
\text { makers and ex- } \\
\text { perts in infec- } \\
\text { tious diseases, } \\
\text { epidemiology, } \\
\text { food safety, } \\
\text { health informat- } \\
\text { ics systems, and } \\
\text { health and tech- } \\
\text { nology law } \\
\text { 2. n=44 } \\
\text { 3. N/A } \\
\text { 4. N/A } \\
\text { 5. Purposive } \\
\text { sampling }\end{array}$ & $\begin{array}{l}\text { Identify ethical } \\
\text { issues in the } \\
\text { adoption and ef- } \\
\text { fective implemen- } \\
\text { tation of a digital } \\
\text { surveillance tool }\end{array}$ & $\begin{array}{l}\text { Early detection of } \\
\text { infectious disease } \\
\text { outbreaks in- } \\
\text { volves lack of so- } \\
\text { cial license or } \\
\text { ethical and legal } \\
\text { considerations. }\end{array}$ & $\begin{array}{l}\text { Mixed } \\
\text { method; on- } \\
\text { line survey; } \\
\text { framework } \\
\text { analysis }\end{array}$ & $\begin{array}{l}\text { Infectious disease } \\
\text { monitoring systems } \\
\text { raise issues such as } \\
\text { personal privacy, } \\
\text { forensic risks, poten- } \\
\text { tial unintended con- } \\
\text { sequences, and the } \\
\text { weakening of public } \\
\text { trust. }\end{array}$ \\
\hline \multicolumn{8}{|l|}{ Reports $(n=24)$} \\
\hline $\begin{array}{l}\text { Sweeney (2020) } \\
{[22]}\end{array}$ & $\begin{array}{l}\text { United } \\
\text { Kingdom }\end{array}$ & $\begin{array}{l}\text { Nature Machine } \\
\text { Intelligence }\end{array}$ & N/A & $\begin{array}{l}\text { Balance protect- } \\
\text { ing public health } \\
\text { with safeguarding } \\
\text { civil rights regard- } \\
\text { ing contact-trac- } \\
\text { ing apps }\end{array}$ & $\begin{array}{l}\text { Contact-tracing } \\
\text { apps were used in } \\
\text { COVID-19 } \\
\text { surveillance but } \\
\text { were less under- } \\
\text { stood by people. }\end{array}$ & $\begin{array}{l}\text { Discussion pa- } \\
\text { per }\end{array}$ & $\begin{array}{l}\text { Contact-tracing apps } \\
\text { debate on protecting } \\
\text { public health with } \\
\text { safeguarding civil } \\
\text { rights. }\end{array}$ \\
\hline $\begin{array}{l}\text { Gilbert et al } \\
(2019)[6]\end{array}$ & Australia & $\begin{array}{l}\text { Asian Bioethics } \\
\text { Review }\end{array}$ & N/A & $\begin{array}{l}\text { Highlight the ur- } \\
\text { gency of having } \\
\text { an ethical frame- } \\
\text { work to guide the } \\
\text { use of new tech- } \\
\text { nologies in com- } \\
\text { municable dis- } \\
\text { ease surveillance } \\
\text { and control }\end{array}$ & $\begin{array}{l}\text { There is consider- } \\
\text { able public oppo- } \\
\text { sition to allowing } \\
\text { public health au- } \\
\text { thorities access to } \\
\text { personal health } \\
\text { data for infec- } \\
\text { tious disease } \\
\text { surveillance. }\end{array}$ & $\begin{array}{l}\text { Discussion pa- } \\
\text { per }\end{array}$ & $\begin{array}{l}\text { Informed public dis- } \\
\text { cussion, greater } \\
\text { transparency, and an } \\
\text { ethical framework } \\
\text { will be essential to } \\
\text { build public trust in } \\
\text { the use of new tech- } \\
\text { nology for communi- } \\
\text { cable disease con- } \\
\text { trol. }\end{array}$ \\
\hline
\end{tabular}




\begin{tabular}{|c|c|c|c|c|c|c|c|}
\hline $\begin{array}{l}\text { Article type, and } \\
\text { authors and year }\end{array}$ & Country & Journal & $\begin{array}{l}\text { 1. Sampling } \\
\text { frame } \\
\text { 2. Sample size } \\
\text { 3. Age } \\
\text { 4. Gender ratio } \\
\text { (F:M) } \\
\text { 5. Sampling } \\
\text { method }\end{array}$ & Study aim & $\begin{array}{l}\text { Context of } \\
\text { studies }\end{array}$ & $\begin{array}{l}\text { Methodology } \\
\text { and methods }\end{array}$ & $\begin{array}{l}\text { Key and relevant } \\
\text { findings }\end{array}$ \\
\hline $\begin{array}{l}\text { Schwalbe et al } \\
(2020)[23]\end{array}$ & $\begin{array}{l}\text { United } \\
\text { States }\end{array}$ & Lancet & N/A & $\begin{array}{l}\text { Artificial intelli- } \\
\text { gence (AI) use in } \\
\text { low- and middle- } \\
\text { income countries }\end{array}$ & $\begin{array}{l}\text { AI-driven inter- } \\
\text { vention research } \\
\text { in global health } \\
\text { has less ad- } \\
\text { dressed ethical, } \\
\text { regulatory, or } \\
\text { practical consider- } \\
\text { ations. }\end{array}$ & $\begin{array}{l}\text { Discussion pa- } \\
\text { per }\end{array}$ & $\begin{array}{l}\text { Addressing privacy } \\
\text { and security in digi- } \\
\text { tal development in- } \\
\text { volves careful con- } \\
\text { sideration of which } \\
\text { data are collected } \\
\text { and how data are ac- } \\
\text { quired, used, stored, } \\
\text { and shared. }\end{array}$ \\
\hline $\begin{array}{l}\text { Garattini et al } \\
(2019) \text { [2] }\end{array}$ & $\begin{array}{l}\text { United } \\
\text { Kingdom }\end{array}$ & $\begin{array}{l}\text { Philosophy \& } \\
\text { Technology }\end{array}$ & N/A & $\begin{array}{l}\text { Provide a moral } \\
\text { foundation for } \\
\text { the societal accep- } \\
\text { tance and respon- } \\
\text { sible develop- } \\
\text { ment of techno- } \\
\text { logical advance- } \\
\text { ment }\end{array}$ & $\begin{array}{l}\text { There are many } \\
\text { ethical impacts } \\
\text { when applying } \\
\text { BDA in infec- } \\
\text { tious diseases. }\end{array}$ & $\begin{array}{l}\text { Discussion pa- } \\
\text { per }\end{array}$ & $\begin{array}{l}\text { Automation and algo- } \\
\text { rithmic reliance im- } \\
\text { pact freedom of } \\
\text { choice; BDA com- } \\
\text { plexity impacts in- } \\
\text { formed consent; re- } \\
\text { liance on profiling } \\
\text { impacts individual } \\
\text { and group identities } \\
\text { and justice/fair ac- } \\
\text { cess; and increased } \\
\text { surveillance and } \\
\text { population interven- } \\
\text { tion capabilities im- } \\
\text { pact behavioral } \\
\text { norms and practices. }\end{array}$ \\
\hline $\begin{array}{l}\text { Parker et al } \\
(2020)[3]\end{array}$ & $\begin{array}{l}\text { United } \\
\text { Kingdom }\end{array}$ & $\begin{array}{l}\text { Journal of Medi- } \\
\text { cal Ethics }\end{array}$ & N/A & $\begin{array}{l}\text { Outline ethical } \\
\text { considerations in } \\
\text { the deployment } \\
\text { of digital surveil- } \\
\text { lance systems for } \\
\text { public health re- } \\
\text { sponse }\end{array}$ & $\begin{array}{l}\text { Mobile phone } \\
\text { contact-tracing } \\
\text { apps have raised } \\
\text { many ethical } \\
\text { questions in the } \\
\text { COVID-19 pan- } \\
\text { demic. }\end{array}$ & $\begin{array}{l}\text { Discussion pa- } \\
\text { per }\end{array}$ & $\begin{array}{l}\text { Privacy, liberty, re- } \\
\text { sponsibilities, data } \\
\text { management, public } \\
\text { trust and confidence, } \\
\text { equity, fairness, jus- } \\
\text { tice, and data consis- } \\
\text { tency need to be ad- } \\
\text { dressed in the de- } \\
\text { ployment of mobile } \\
\text { phone apps. }\end{array}$ \\
\hline $\begin{array}{l}\text { Katapally (2020) } \\
{[24]}\end{array}$ & Canada & $\begin{array}{l}\text { Journal of Medi- } \\
\text { cal Internet Re- } \\
\text { search }\end{array}$ & N/A & $\begin{array}{l}\text { Outline an evi- } \\
\text { dence-based } \\
\text { global digital citi- } \\
\text { zen science poli- } \\
\text { cy, which pro- } \\
\text { vides a theoreti- } \\
\text { cal and method- } \\
\text { ological basis for } \\
\text { ethically sourcing } \\
\text { big data from citi- } \\
\text { zens to tackle } \\
\text { pandemics such } \\
\text { as COVID-19 }\end{array}$ & $\begin{array}{l}\text { A cohesive soci- } \\
\text { etal effort with } \\
\text { citizens' full sup- } \\
\text { port is needed in } \\
\text { pandemics. }\end{array}$ & $\begin{array}{l}\text { Discussion pa- } \\
\text { per }\end{array}$ & $\begin{array}{l}\text { One of the biggest } \\
\text { ethical challenges is } \\
\text { data privacy and se- } \\
\text { curity. Individuals' } \\
\text { rights to privacy and } \\
\text { anonymity through } \\
\text { advanced encryption } \\
\text { and secure server } \\
\text { storage processes, } \\
\text { informed consent, } \\
\text { the ability to dropout } \\
\text { and delete their own } \\
\text { data, and data co- } \\
\text { ownership, should } \\
\text { be priorities. }\end{array}$ \\
\hline
\end{tabular}




\begin{tabular}{|c|c|c|c|c|c|c|c|}
\hline $\begin{array}{l}\text { Article type, and } \\
\text { authors and year }\end{array}$ & Country & Journal & $\begin{array}{l}\text { 1. Sampling } \\
\text { frame } \\
\text { 2. Sample size } \\
\text { 3. Age } \\
\text { 4. Gender ratio } \\
\text { (F:M) } \\
\text { 5. Sampling } \\
\text { method }\end{array}$ & Study aim & $\begin{array}{l}\text { Context of } \\
\text { studies }\end{array}$ & $\begin{array}{l}\text { Methodology } \\
\text { and methods }\end{array}$ & $\begin{array}{l}\text { Key and relevant } \\
\text { findings }\end{array}$ \\
\hline $\begin{array}{l}\text { Mbunge (2020) } \\
{[25]}\end{array}$ & Eswatini & $\begin{array}{l}\text { Diabetes \& } \\
\text { Metabolic Syn- } \\
\text { drome: Clinical } \\
\text { Research \& Re- } \\
\text { views }\end{array}$ & N/A & $\begin{array}{l}\text { Analyze the po- } \\
\text { tential opportuni- } \\
\text { ties and chal- } \\
\text { lenges of integrat- } \\
\text { ing emerging } \\
\text { technologies, in- } \\
\text { cluding } 5 \mathrm{G} \text { tech- } \\
\text { nology, AI, and } \\
\text { big data, into } \\
\text { COVID-19 con- } \\
\text { tact tracking }\end{array}$ & $\begin{array}{l}\text { Contact-tracing } \\
\text { technologies have } \\
\text { limitations when } \\
\text { used in the } \\
\text { COVID-19 pan- } \\
\text { demic. }\end{array}$ & $\begin{array}{l}\text { Literature re- } \\
\text { view }\end{array}$ & $\begin{array}{l}\text { Ethical or legal chal- } \\
\text { lenges might be so- } \\
\text { cioeconomic inequal- } \\
\text { ities in developing } \\
\text { counties; security } \\
\text { risks such as data se- } \\
\text { curity, confidentiali- } \\
\text { ty, integrity, and da- } \\
\text { ta availability of pa- } \\
\text { tients and contacts in } \\
\text { COVID-19; the pri- } \\
\text { vacy issues of pa- } \\
\text { tients, which may } \\
\text { lead to mental health } \\
\text { problems; consent } \\
\text { and voluntariness; } \\
\text { and discrimination. }\end{array}$ \\
\hline $\begin{array}{l}\text { Garg et al (2020) } \\
{[26]}\end{array}$ & India & $\begin{array}{l}\text { JMIR Public } \\
\text { Health and } \\
\text { Surveillance }\end{array}$ & N/A & $\begin{array}{l}\text { Describe Aaro- } \\
\text { gya Setu, a first- } \\
\text { of-its-kind partic- } \\
\text { ipatory disease } \\
\text { surveillance initia- } \\
\text { tive in India and } \\
\text { its ethical consid- } \\
\text { erations }\end{array}$ & $\begin{array}{l}\text { Opt-in, data in- } \\
\text { tegrity, and ethi- } \\
\text { cal concerns need } \\
\text { to be addressed } \\
\text { when using the } \\
\text { new system for } \\
\text { the COVID-19 } \\
\text { pandemic. }\end{array}$ & Case report & $\begin{array}{l}\text { The main ethical } \\
\text { dilemma is how to } \\
\text { ensure data protec- } \\
\text { tion and proper } \\
\text { ethics while obtain- } \\
\text { ing the benefits of } \\
\text { public health } \\
\text { surveillance, and } \\
\text { how to ensure the } \\
\text { ethical use of collect- } \\
\text { ed data and protect } \\
\text { individual privacy. }\end{array}$ \\
\hline $\begin{array}{l}\text { Denecke (2017) } \\
{[27]}\end{array}$ & $\begin{array}{l}\text { Switzer- } \\
\text { land }\end{array}$ & $\begin{array}{l}\text { Life Sciences, } \\
\text { Society and } \\
\text { Policy }\end{array}$ & N/A & $\begin{array}{l}\text { Highlight the eth- } \\
\text { ical issues that } \\
\text { should be consid- } \\
\text { ered when inte- } \\
\text { grating digital } \\
\text { epidemiology } \\
\text { with current prac- } \\
\text { tice and develop } \\
\text { an ethical assess- } \\
\text { ment model for } \\
\text { digital disease } \\
\text { detection (DDD) } \\
\text { technologies }\end{array}$ & $\begin{array}{l}\text { Usage of digital } \\
\text { surveillance in } \\
\text { epidemiology has } \\
\text { different kinds of } \\
\text { challenges. }\end{array}$ & $\begin{array}{l}\text { Discussion pa- } \\
\text { per }\end{array}$ & $\begin{array}{l}\text { The model devel- } \\
\text { oped in this study } \\
\text { might help to make } \\
\text { aware the ethical as- } \\
\text { pects already in the } \\
\text { development pro- } \\
\text { cess, and possibly } \\
\text { address them. }\end{array}$ \\
\hline
\end{tabular}




\begin{tabular}{|c|c|c|c|c|c|c|c|}
\hline $\begin{array}{l}\text { Article type, and } \\
\text { authors and year }\end{array}$ & Country & Journal & $\begin{array}{l}\text { 1. Sampling } \\
\text { frame } \\
\text { 2. Sample size } \\
\text { 3. Age } \\
\text { 4. Gender ratio } \\
\text { (F:M) } \\
\text { 5. Sampling } \\
\text { method }\end{array}$ & Study aim & $\begin{array}{l}\text { Context of } \\
\text { studies }\end{array}$ & $\begin{array}{l}\text { Methodology } \\
\text { and methods }\end{array}$ & $\begin{array}{l}\text { Key and relevant } \\
\text { findings }\end{array}$ \\
\hline $\begin{array}{l}\text { Kostkova (2018) } \\
{[28]}\end{array}$ & $\begin{array}{l}\text { United } \\
\text { Kingdom }\end{array}$ & $\begin{array}{l}\text { Life Sciences, } \\
\text { Society and } \\
\text { Policy }\end{array}$ & N/A & $\begin{array}{l}\text { Outline } 3 \text { major } \\
\text { ethical and gover- } \\
\text { nance challenges } \\
\text { for digital epi- } \\
\text { demiology in the } \\
21 \text { st century }\end{array}$ & $\begin{array}{l}\text { Digital surveil- } \\
\text { lance has created } \\
\text { ethical, political, } \\
\text { and legal chal- } \\
\text { lenges in infec- } \\
\text { tious disease con- } \\
\text { trol. }\end{array}$ & $\begin{array}{l}\text { Commentary } \\
\text { report }\end{array}$ & $\begin{array}{l}\text { Some of the ethical } \\
\text { challenges of shar- } \\
\text { ing data across vari- } \\
\text { ous early warning } \\
\text { tools to support risk } \\
\text { assessment are own- } \\
\text { ership of personal } \\
\text { data, transparency } \\
\text { and clarity of public } \\
\text { health data sharing, } \\
\text { strong transparent } \\
\text { disclosure, data pri- } \\
\text { vacy and security, } \\
\text { and the balance be- } \\
\text { tween data sharing, } \\
\text { personal data protec- } \\
\text { tion, stakeholder } \\
\text { needs, and public } \\
\text { good. }\end{array}$ \\
\hline $\begin{array}{l}\text { Vayena et al } \\
(2015) \text { [29] }\end{array}$ & $\begin{array}{l}\text { Switzer- } \\
\text { land }\end{array}$ & $\begin{array}{l}\text { PLoS Computa- } \\
\text { tional Biology }\end{array}$ & N/A & $\begin{array}{l}\text { Identify key ethi- } \\
\text { cal challenges as- } \\
\text { sociated with } \\
\text { DDD activities } \\
\text { and outline a } \\
\text { framework for } \\
\text { addressing them }\end{array}$ & $\begin{array}{l}\text { DDD has many } \\
\text { ethical challenges } \\
\text { in infectious dis- } \\
\text { ease pandemics. }\end{array}$ & $\begin{array}{l}\text { Discussion pa- } \\
\text { per }\end{array}$ & $\begin{array}{l}\text { The ethical chal- } \\
\text { lenges of DDD can } \\
\text { be divided under } 3 \\
\text { heads: context sensi- } \\
\text { tivity (privacy and } \\
\text { contextual integrity, } \\
\text { transparency, and } \\
\text { global justice); } \\
\text { nexus of ethics and } \\
\text { methodology (risk of } \\
\text { harm, use of re- } \\
\text { sources, trust, trans- } \\
\text { parency, accountabil- } \\
\text { ity); and legitimacy } \\
\text { requirements (shared } \\
\text { code of practice, } \\
\text { mechanism for quick } \\
\text { response to inaccura- } \\
\text { cies, addressing } \\
\text { harms caused by } \\
\text { DDD activities, } \\
\text { common good). }\end{array}$ \\
\hline
\end{tabular}




\begin{tabular}{|c|c|c|c|c|c|c|c|}
\hline $\begin{array}{l}\text { Article type, and } \\
\text { authors and year }\end{array}$ & Country & Journal & $\begin{array}{l}\text { 1. Sampling } \\
\text { frame } \\
\text { 2. Sample size } \\
\text { 3. Age } \\
\text { 4. Gender ratio } \\
\text { (F:M) } \\
\text { 5. Sampling } \\
\text { method }\end{array}$ & Study aim & $\begin{array}{l}\text { Context of } \\
\text { studies }\end{array}$ & $\begin{array}{l}\text { Methodology } \\
\text { and methods }\end{array}$ & $\begin{array}{l}\text { Key and relevant } \\
\text { findings }\end{array}$ \\
\hline $\begin{array}{l}\text { De Jong et al } \\
(2019)[30]\end{array}$ & Belgium & $\begin{array}{l}\text { Emerging Infec- } \\
\text { tious Diseases }\end{array}$ & N/A & $\begin{array}{l}\text { Mitigate the ethi- } \\
\text { cal concerns of } \\
\text { movement map- } \\
\text { ping of potential- } \\
\text { ly infected per- } \\
\text { sons }\end{array}$ & $\begin{array}{l}\text { Mapping the } \\
\text { movements of } \\
\text { potentially infect- } \\
\text { ed persons has } \\
\text { ethical chal- } \\
\text { lenges. }\end{array}$ & $\begin{array}{l}\text { Discussion pa- } \\
\text { per }\end{array}$ & $\begin{array}{l}\text { Ethical obstacles are } \\
\text { privacy in relation to } \\
\text { the principles of au- } \\
\text { tonomy and non- } \\
\text { maleficence; and a } \\
\text { balance between } \\
\text { costs, risks, and ben- } \\
\text { efits for participants } \\
\text { and communities in } \\
\text { relation to the princi- } \\
\text { ples of beneficence } \\
\text { and justice, such as } \\
\text { stigmatized commu- } \\
\text { nity, data withhold- } \\
\text { ing, and whether and } \\
\text { how to communicate } \\
\text { information on } \\
\text { hotspots to the gener- } \\
\text { al population. }\end{array}$ \\
\hline Kind (2020) [31] & $\begin{array}{l}\text { United } \\
\text { Kingdom }\end{array}$ & Patterns & N/A & $\begin{array}{l}\text { Examine societal, } \\
\text { political, legal } \\
\text { and ethical per- } \\
\text { spectives on } \\
\text { symptom track- } \\
\text { ing, contact trac- } \\
\text { ing, and immuni- } \\
\text { ty }\end{array}$ & $\begin{array}{l}\text { The UK govern- } \\
\text { ment asked for } \\
\text { more information } \\
\text { to decide the use } \\
\text { of technology in } \\
\text { the COVID-19 } \\
\text { pandemic. }\end{array}$ & $\begin{array}{l}\text { Rapid evi- } \\
\text { dence review }\end{array}$ & $\begin{array}{l}\text { The ethical issues of } \\
\text { digital contact trac- } \\
\text { ing are human rights } \\
\text { and data protection, } \\
\text { inequalities, data } \\
\text { quality limitations, } \\
\text { false reporting risks, } \\
\text { and centralization of } \\
\text { large amounts of } \\
\text { personal data. }\end{array}$ \\
\hline $\begin{array}{l}\text { Park et al (2020) } \\
{[32]}\end{array}$ & Korea & JAMA & N/A & $\begin{array}{l}\text { Identify ethical } \\
\text { concerns over } \\
\text { privacy involving } \\
\text { the information } \\
\text { technolo- } \\
\text { gy-based tracing } \\
\text { strategy in re- } \\
\text { sponse to } \\
\text { COVID-19 }\end{array}$ & $\begin{array}{l}\text { South Korea ex- } \\
\text { tensively used } \\
\text { digital tools for } \\
\text { tracing COVID- } \\
19 \text { patients. }\end{array}$ & $\begin{array}{l}\text { Discussion pa- } \\
\text { per }\end{array}$ & $\begin{array}{l}\text { Privacy controver- } \\
\text { sies might unveil or } \\
\text { infer embarrassing } \\
\text { personal details, un- } \\
\text { wanted privacy inva- } \\
\text { sion, public disdain, } \\
\text { uneven scope, and } \\
\text { granularity of disclo- } \\
\text { sures by municipal } \\
\text { and local govern- } \\
\text { ments. }\end{array}$ \\
\hline $\begin{array}{l}\text { Fraser et al } \\
(2020) \text { [33] }\end{array}$ & $\begin{array}{l}\text { United } \\
\text { Kingdom }\end{array}$ & $\begin{array}{l}\text { University of } \\
\text { Oxford }\end{array}$ & N/A & $\begin{array}{l}\text { Minimize the in- } \\
\text { vasion of privacy } \\
\text { by using digital } \\
\text { contact tracing }\end{array}$ & $\begin{array}{l}\text { Contact tracing } \\
\text { was used to assist } \\
\text { people in receiv- } \\
\text { ing warnings } \\
\text { about COVID- } \\
19 .\end{array}$ & $\begin{array}{l}\text { Discussion pa- } \\
\text { per }\end{array}$ & $\begin{array}{l}\text { The ethical issues } \\
\text { include sensitively } \\
\text { and specifically } \\
\text { identifying infec- } \\
\text { tious individuals, us- } \\
\text { er uptake and adher- } \\
\text { ence, notification, } \\
\text { integration with lo- } \\
\text { cal health policy, } \\
\text { and ability to evalu- } \\
\text { ate effectiveness } \\
\text { transparently. }\end{array}$ \\
\hline
\end{tabular}




\begin{tabular}{|c|c|c|c|c|c|c|c|}
\hline $\begin{array}{l}\text { Article type, and } \\
\text { authors and year }\end{array}$ & Country & Journal & $\begin{array}{l}\text { 1. Sampling } \\
\text { frame } \\
\text { 2. Sample size } \\
\text { 3. Age } \\
\text { 4. Gender ratio } \\
\text { (F:M) } \\
\text { 5. Sampling } \\
\text { method }\end{array}$ & Study aim & $\begin{array}{l}\text { Context of } \\
\text { studies }\end{array}$ & $\begin{array}{l}\text { Methodology } \\
\text { and methods }\end{array}$ & $\begin{array}{l}\text { Key and relevant } \\
\text { findings }\end{array}$ \\
\hline $\begin{array}{l}\text { Cho et al (2020) } \\
{[34]}\end{array}$ & $\begin{array}{l}\text { Singa- } \\
\text { pore }\end{array}$ & ArXiv Preprint & N/A & $\begin{array}{l}\text { Discuss ways of } \\
\text { ameliorating pri- } \\
\text { vacy concerns } \\
\text { without decreas- } \\
\text { ing the usefulness } \\
\text { of contact-tracing } \\
\text { apps }\end{array}$ & $\begin{array}{l}\text { The Singaporean } \\
\text { government re- } \\
\text { leased a mobile } \\
\text { phone app to as- } \\
\text { sist in tracking } \\
\text { down exposures } \\
\text { to COVID-19 pa- } \\
\text { tients, but there } \\
\text { were privacy im- } \\
\text { plications. }\end{array}$ & $\begin{array}{l}\text { Discussion pa- } \\
\text { per }\end{array}$ & $\begin{array}{l}\text { Privacy is a central } \\
\text { feature of conversa- } \\
\text { tions around mobile } \\
\text { contact-tracking } \\
\text { apps. Some privacy } \\
\text { trade-offs can be en- } \\
\text { dured for public } \\
\text { health. }\end{array}$ \\
\hline $\begin{array}{l}\text { Klenk et al } \\
(2020) \text { [35] }\end{array}$ & $\begin{array}{l}\text { Nether- } \\
\text { lands }\end{array}$ & $\begin{array}{l}\text { Ethics and Infor- } \\
\text { mation Technol- } \\
\text { ogy }\end{array}$ & N/A & $\begin{array}{l}\text { Identify factors } \\
\text { that pose a risk } \\
\text { for fair group } \\
\text { composition }\end{array}$ & $\begin{array}{l}\text { Digital tracing } \\
\text { technologies for } \\
\text { COVID-19 con- } \\
\text { trol were reported } \\
\text { to have ethical } \\
\text { risks. }\end{array}$ & $\begin{array}{l}\text { Discussion pa- } \\
\text { per }\end{array}$ & $\begin{array}{l}\text { Digital tracking apps } \\
\text { will introduce new } \\
\text { psychological, so- } \\
\text { cial, economic, and } \\
\text { political risks. }\end{array}$ \\
\hline $\begin{array}{l}\text { De Montjoye et } \\
\text { al }(2020)[36]\end{array}$ & $\begin{array}{l}\text { United } \\
\text { Kingdom }\end{array}$ & $\begin{array}{l}\text { Computational } \\
\text { Privacy Group } \\
\text { Blog }\end{array}$ & N/A & $\begin{array}{l}\text { Propose } 8 \text { ques- } \\
\text { tions to assess } \\
\text { privacy in con- } \\
\text { tact-tracing apps. }\end{array}$ & $\begin{array}{l}\text { A contact-tracing } \\
\text { app was devel- } \\
\text { oped to assist } \\
\text { with COVID-19 } \\
\text { control, and } \\
\text { record location or } \\
\text { close contact da- } \\
\text { ta. }\end{array}$ & $\begin{array}{l}\text { Discussion pa- } \\
\text { per }\end{array}$ & $\begin{array}{l}\text { Privacy protection } \\
\text { should rely on math- } \\
\text { ematical proof, and } \\
\text { mitigation strategies } \\
\text { should be considered } \\
\text { only when neces- } \\
\text { sary. We should fo- } \\
\text { cus on privacy and } \\
\text { ensure security. }\end{array}$ \\
\hline $\begin{array}{l}\text { Bernier et al } \\
(2015)[37]\end{array}$ & Canada & $\begin{array}{l}\text { University of } \\
\text { New Brunswick } \\
\text { Law Journal }\end{array}$ & N/A & $\begin{array}{l}\text { Highlight the per- } \\
\text { sonal privacy in } \\
\text { electronic public } \\
\text { health surveil- } \\
\text { lance systems }\end{array}$ & $\begin{array}{l}\text { Data surveillance } \\
\text { has become a key } \\
\text { component of } \\
\text { pandemic re- } \\
\text { sponse plans. }\end{array}$ & $\begin{array}{l}\text { Discussion pa- } \\
\text { per }\end{array}$ & $\begin{array}{l}\text { The privacy gover- } \\
\text { nance framework is } \\
\text { incomplete in ensur- } \\
\text { ing the effective and } \\
\text { protective use of } \\
\text { personal information } \\
\text { in response to epi- } \\
\text { demics. }\end{array}$ \\
\hline $\begin{array}{l}\text { Ienca et al (2020) } \\
{[38]}\end{array}$ & $\begin{array}{l}\text { Switzer- } \\
\text { land }\end{array}$ & $\begin{array}{l}\text { Nature } \\
\text { Medicine }\end{array}$ & N/A & $\begin{array}{l}\text { Identify ethical } \\
\text { issues when us- } \\
\text { ing digital } \\
\text { surveillance sys- } \\
\text { tems in COVID- } \\
19\end{array}$ & $\begin{array}{l}\text { The COVID-19 } \\
\text { emergency has } \\
\text { used much more } \\
\text { digital tools than } \\
\text { previous out- } \\
\text { breaks globally. }\end{array}$ & $\begin{array}{l}\text { Discussion pa- } \\
\text { per }\end{array}$ & $\begin{array}{l}\text { Best practices } \\
\text { should be identified } \\
\text { to protect privacy } \\
\text { and public trust. }\end{array}$ \\
\hline $\begin{array}{l}\text { Yasaka et al } \\
(2020) \text { [39] }\end{array}$ & $\begin{array}{l}\text { United } \\
\text { States }\end{array}$ & $\begin{array}{l}\text { JMIR mHealth } \\
\text { and uHealth }\end{array}$ & N/A & $\begin{array}{l}\text { Develop an effec- } \\
\text { tive contact-trac- } \\
\text { ing smartphone } \\
\text { app that respects } \\
\text { user privacy by } \\
\text { not collecting lo- } \\
\text { cation informa- } \\
\text { tion or other per- } \\
\text { sonal data }\end{array}$ & $\begin{array}{l}\text { Smartphone- } \\
\text { based contact } \\
\text { tracing has been } \\
\text { used in the } \\
\text { COVID-19 pan- } \\
\text { demic to limit } \\
\text { disease transmis- } \\
\text { sion. }\end{array}$ & $\begin{array}{l}\text { Discussion pa- } \\
\text { per }\end{array}$ & $\begin{array}{l}\text { Users may be uncom- } \\
\text { fortable with applica- } \\
\text { tions that track real- } \\
\text { time locations. }\end{array}$ \\
\hline
\end{tabular}




\begin{tabular}{|c|c|c|c|c|c|c|c|}
\hline $\begin{array}{l}\text { Article type, and } \\
\text { authors and year }\end{array}$ & Country & Journal & $\begin{array}{l}\text { 1. Sampling } \\
\text { frame } \\
\text { 2. Sample size } \\
\text { 3. Age } \\
\text { 4. Gender ratio } \\
\text { (F:M) } \\
\text { 5. Sampling } \\
\text { method }\end{array}$ & Study aim & $\begin{array}{l}\text { Context of } \\
\text { studies }\end{array}$ & $\begin{array}{l}\text { Methodology } \\
\text { and methods }\end{array}$ & $\begin{array}{l}\text { Key and relevant } \\
\text { findings }\end{array}$ \\
\hline $\begin{array}{l}\text { Barbieri et al } \\
(2020) \text { [40] }\end{array}$ & Italy & $\begin{array}{l}\text { Istituto Affari } \\
\text { Internazionali }\end{array}$ & N/A & $\begin{array}{l}\text { Discuss the ethics } \\
\text { of technological } \\
\text { solutions to miti- } \\
\text { gate COVID-19 }\end{array}$ & $\begin{array}{l}\text { Technological so- } \\
\text { lutions to miti- } \\
\text { gate the COVID- } \\
19 \text { crisis have } \\
\text { been implement- } \\
\text { ed in China and } \\
\text { South Korea. }\end{array}$ & $\begin{array}{l}\text { Discussion pa- } \\
\text { per }\end{array}$ & $\begin{array}{l}\text { In a pandemic crisis, } \\
\text { the balance between } \\
\text { privacy and public } \\
\text { health tends to tilt } \\
\text { toward the latter. } \\
\text { However, a strong } \\
\text { legal framework } \\
\text { should be estab- } \\
\text { lished around any } \\
\text { such data-driven } \\
\text { policy, taking into } \\
\text { account the transi- } \\
\text { tion to "postepidem- } \\
\text { ic" life. }\end{array}$ \\
\hline $\begin{array}{l}\text { Chan et al (2020) } \\
\text { [41] }\end{array}$ & $\begin{array}{l}\text { United } \\
\text { States }\end{array}$ & arXiv & N/A & $\begin{array}{l}\text { Improve the priva- } \\
\text { cy and anonymity } \\
\text { standards of mo- } \\
\text { bile contact trac- } \\
\text { ing }\end{array}$ & $\begin{array}{l}\text { The COVID-19 } \\
\text { pandemic has } \\
\text { been controlled } \\
\text { by large-scale } \\
\text { adoption of con- } \\
\text { tact tracing. }\end{array}$ & $\begin{array}{l}\text { Discussion pa- } \\
\text { per }\end{array}$ & $\begin{array}{l}\text { Ethical issues of pri- } \\
\text { vacy protection, } \\
\text { transparency, and } \\
\text { reidentification risks } \\
\text { of anonymous infor- } \\
\text { mation. }\end{array}$ \\
\hline Peter (2020) [42] & Australia & The Guardian & N/A & $\begin{array}{l}\text { Discuss the ac- } \\
\text { ceptability of a } \\
\text { coronavirus trac- } \\
\text { ing app by Aus- } \\
\text { tralians and how } \\
\text { to implement } \\
\text { tracing technolo- } \\
\text { gy successfully }\end{array}$ & $\begin{array}{l}\text { The Australian } \\
\text { public is seeking } \\
\text { a way to manage } \\
\text { the COVID-19 } \\
\text { pandemic. }\end{array}$ & $\begin{array}{l}\text { Discussion pa- } \\
\text { per }\end{array}$ & $\begin{array}{l}\text { The ultimate success } \\
\text { of tracking technolo- } \\
\text { gy will depend on } \\
\text { confidence and mutu- } \\
\text { al respect. The ulti- } \\
\text { mate test of any } \\
\text { tracking technology } \\
\text { will be the strength } \\
\text { of the relationship } \\
\text { between the public } \\
\text { and the government. }\end{array}$ \\
\hline
\end{tabular}

${ }^{\mathrm{a} N} / \mathrm{A}$ : not applicable.

\section{Ethical Issues}

Textbox 1 shows the key ethical issues identified in the review summarized and clustered under individual, organizational, and societal levels with key themes presented under the corresponding concepts. Six domains, namely awareness of implementing digital infectious disease surveillance, digital integrity, trust, privacy and confidentiality, civil rights, and governance were highlighted. 
Textbox 1. Ethical issues in utilizing artificial intelligence-augmented infectious disease surveillance systems based on the ethical framework of Asadi et al [15].

\section{Individual level}

Data ownership

- Digital infectious disease surveillance systems challenge data ownerships rights

- Impacts of data ownership rights on public participation in digital infectious disease surveillance

Data control

- Inappropriate reidentification, sharing, or processing of personal information of infectious disease patients

Awareness

- Lack of understanding of data collection, access, processing, sharing, and storage of infectious disease surveillance systems

- Lack of and inability to give consent when enrolled into infectious disease surveillance systems

Trust

- Data governance, security, and data set bias undermines public trust

- Public mistrust in the necessity and effectiveness of contact-tracing technology for infectious diseases

- Public mistrust in governments' strategies in using digital infectious disease surveillance

Privacy

- Concerns of privacy risks and allowance to infectious disease control

- Privacy risks on contact tracing for infectious diseases and social networks

- Disclosure of infectious disease information leads to business depletion, privacy invasion, and public disdain

- Necessity of infectious disease data anonymization and risk of reidentification

- Privacy and appropriate authority oversight on artificial intelligence (AI)-augmented infectious disease surveillance systems

Self-determination

- Autonomy/personal liberty to participate in and use AI-augmented infectious disease surveillance systems

Fear

- Fears of privacy violation, institutional control/penalties, and discriminatory/stigmatized effects when using AI-augmented infectious disease surveillance systems

\section{Organizational level}

Data quality

- Data accuracy, validity, veracity, and integrity of AI-augmented infectious disease surveillance systems

- Consequences of low data quality in AI-augmented infectious disease surveillance systems

Data sourcing

- Vulnerable populations/key demographics underrepresented in data sourcing could lead to invalid infectious disease control

Data sharing/disclosure

- Data sharing/disclosure for unethical purpose when using AI-augmented infectious disease surveillance systems

- Data disclosure needs clear standards and safeguards when using AI-augmented infectious disease surveillance systems

Algorithmic decision making

- Reliability, validity, and consequences of algorithmic decision making for infectious disease outbreaks

- Vulnerability of machine learning processes for infectious disease surveillance

Presentation

- Needs for transparent and clear presentation of algorithms, data processing, and hotspots of infectious diseases 
Ethical capability

- Lack of ethical training on data collection and disciplinary measures on poor data quality for infectious disease surveillance

Ethical culture

- Consideration of cultural contexts in data collection, processing, and decision making for infectious disease surveillance

Ethical governance

- Transparency of digital infectious disease surveillance systems

- Lack of common technical or ethical standards for data usage in infectious disease surveillance

- Lack of an ethical governance framework to regulate algorithms, data collection, use, and management for infectious disease surveillance

Societal level

Power

- Imbalanced power relations among decision makers, researchers, and citizens when using AI-augmented infectious disease surveillance systems

- Unequal allocation and distribution of resources and benefits when using AI-augmented infectious disease surveillance systems

Social awareness

- Social awareness in purpose, risks and benefits, and consequences when setting up infectious disease surveillance programs

Surveillance

- Ethical surveillance with full public engagement and incentives when using AI-augmented infectious disease surveillance systems

- Ensure infectious disease surveillance systems protect civil liberties and rights

Principles and guidelines

- Lack of legislation and guidelines for infectious disease outbreaks and protection of data security, individual privacy, and discrimination

Authority

- The possibility of data misuse by authorities/agencies without legal authorization

Climate

- Digital infectious disease surveillance in a social environment leads to social stigma, discrimination, rumors, and prejudice

\section{Awareness of Implementing Digital Infectious Disease Surveillance}

The informants reported insufficient understanding at every stage of data collection and distribution of digital infectious disease surveillance systems. They felt they were not informed of their rights to refuse or their ability to withdraw consent. Irresponsible decision making was identified by infectious disease patients in relation to insufficient information provided about contact tracing technology. At the societal level, digital infectious disease surveillance based on BDA was poorly accepted by the general public due to their uncertainty about its purpose and the risks posed from the potential mitigation of data sharing. Consequently, they wanted more information about the digital infectious disease surveillance systems and wanted their associated ethical concerns and consequences addressed. They also expected organizations to make public and transparent the algorithms and data processes used, and use plain language when explaining infectious disease surveillance. Simultaneously, both the general public and field experts emphasized that governments or institutions should convey the importance of infectious disease outbreak control to communities without violating ethical principles.

\section{Data Integrity}

Data integrity weaknesses were identified as common in BDA. Unreliable or invalidated data sourcing or algorithms were seen to lead to inaccurate identification of outbreaks or infected individuals, false predication of an event's trajectory or the likelihood of reoccurrence, and inaccurate notifications. The outcomes, such as inadequate data integrity, were further seen to continuously intensify economic losses to trade, tourism, and health services, causing unnecessary panic and the loss of public trust in health authorities. Some organizations and experts also worried that digital infectious disease surveillance systems would widen existing health care disparities or digital divides by underrepresenting vulnerable and at-risk populations such as older adults, children, and people in economically underresourced areas; for instance, data of COVID-19 hotspots influenced the allocation and distribution of resources [25]. It was recommended that digital infectious disease surveillance applications should consider ethical requirements and the rights of people from diverse regions and communities. 


\section{Trust}

Some people questioned the necessity and effectiveness of using contact-tracing technologies in an AI-assumed situation. They mistrusted the AI-augmented systems' capacity to send correct notifications to infected individuals to instruct them to quarantine during an infectious disease outbreak in a timely manner. Emerging technology risks, such as data breaches or data set biases and government strategies of mandatory application of digital contact tracing, could further undermine public trust. Individuals and relevant experts called for an open debate or scrutiny, transparent procedures for data usage, and public consultation plans and privacy regulations.

\section{Privacy and Confidentiality}

Digital infectious disease surveillance was identified to pose considerable risks to an individual's rights to privacy and confidentiality. Contact tracing that linked a potential infectious disease with patients' movements, locations, or social networks was seen as a considerable threat to further disclosure of sensitive information. For example, personal social interactions and contact history, especially in the case of sexually transmitted infections or HIV, could be revealed. Individuals were concerned that third parties or malicious users might access large health data sets for profit and/or abuse. Disclosure of private information was seen to lead to business depletion, privacy invasion, and public discrimination and stigmatization. Data anonymity, robust encryption processes, and deidentified aggregate data were contended to be crucial to all data privacy and security procedures in compliance with data protection regulations.

\section{Civil Rights}

Data ownership rights for public health surveillance were regarded as a major ethical challenge. Some reported that authorities or institutions limited their rights to decide the adoption of digital infectious disease contact tracing or surveillance systems. Personal liberties were also impacted by movement mapping, cross-border sharing of personal health information, and frequent security checks using QR codes for filling in personal information. Countries using centralized contact-tracing apps and privacy-by-design apps were seen to have the potential to impose restrictions on civil liberties, which, in turn, impacted ethical engagement in digital health. Data co-ownership and strengthening of transparency were seen as helpful to encourage individuals to participate in data visualization, analysis, and knowledge translation, and balance the power dynamics among decision makers, researchers, and citizens.

\section{Governance}

Technical and ethical standards, as well as legislation and guidelines for infectious disease outbreaks, data security, protection of individual privacy, and avoidance of discrimination were considered poorly developed and incomplete. Technology companies were recommended to establish a mechanism to deal with inaccurate epidemic reporting and dissemination of misinformation, and were expected to develop rapid ethical assessment, training, and disciplinary measures for data collection or sharing. Governance institutions or bodies, such as national health commissions, medical councils, and company boards, were further recommended to provide appropriate oversight on the performance of algorithms and data usage. Some literature argued that an independent privacy audit was needed to secure a transparent approach for the public $[33,36]$. Both individuals and relevant experts also supported data sharing protocols to specify the scope and granularity of disclosure. An example provided was that personal names should not be publicly available, and personal information should only be gathered and shared within a period of time regulated by law and clearly justified based on population health needs.

\section{Discussion}

\section{Challenges of Using AI Surveillance Systems for Infectious Diseases}

The emergence of AI surveillance systems for infectious diseases promises tangible global public health benefits, but these are accompanied by significant ethical, political, and legal challenges, which span over a wide spectrum on 3 levels. Six main themes were generated from this systematic review, ranging from people's awareness and knowledge of digital infectious disease surveillance systems and personal privacy on the individual level to organizational issues of maintaining data integrity and security, and the lens was extended upward to the societal level, involving public trust, civil rights, and the need for a governance framework with ethical oversights. Some of the challenges are inherent to public health practice and only heightened by the use of digital tools, and others, such as public trust and awareness of digital surveillance, algorithmic decision making, and data security, are specific to AI approaches and largely unprecedented. It is vital to consider these challenges to enhance individuals' rights, privacy, public responsibilities, and optimal population health outcomes so that digital surveillance can tackle pandemics ethically.

\section{Strengths and Limitations}

Studies and position papers on the ethical implications of AI surveillance for infectious diseases have gained momentum since 2019 in response to the outbreak of the COVID-19 pandemic; the dearth of studies prior to this makes it challenging to reveal any time trends. Furthermore, most articles included in the review were discussion papers, limiting the ability to evaluate generalizability, transferability, and rigor or multiple stakeholders' perspectives on the use of AI-augmented infectious disease surveillance. The 5 empirical studies had restricted sampling approaches both in terms of size and stakeholder representation (health professionals and community groups), with 4 of the studies being conducted in Australia alone. Few papers involved vulnerable or diverse populations, and none involved specific cultural or socioeconomic groups, further limiting the scope of the review. Furthermore, articles acknowledged the inherent strengths and weaknesses of the public health system operating at the location of the study.

\section{Retributions Versus Common Good for Public Health and Long-term Impacts}

The tensions between human and civil right discourses and the need for rapid public health responses are exacerbated with the 
use of BDA/AI in the context of a pandemic [2]. There are medicolegal and moral retributions and concerns arising from utilizing available epidemiological information through a highly effective and responsive infectious disease surveillance method that could protect local and, potentially, global communities from serious infectious disease outbreaks $[3,18]$. Conversely, routine collection and linkage of detailed personal information pose considerable risks for the violation of individual and civil freedoms of choice and privacy [19].

As of July 21, 2021, there have been 191 million confirmed cases and 4.11 million deaths globally from COVID-19 [43]. Given that sound public health interventions are predicated upon promoting and protecting the health of communities, timely, cost-effective, and socioculturally informed primary care interventions, advocacy, and empowerment with long-term impact evaluations are required. There are strong reasons to develop an ethical governance framework to support AI-augmented infectious disease surveillance to achieve these outcomes. The question of how to balance what is needed for the "good of public health outcomes" and human rights in pandemic crisis situations is highlighted in the literature reviewed [33,37].

\section{Trust Building and Privacy Protection}

Detection and notification of infectious disease outbreaks requires prompt accurate disease diagnosis and follow-up of infected individuals and their close contacts. An early AI-augmented warning system has exponential potential for implementing real-time, responsive, and adaptive calculations. This means that substantial personal information, such as names, ages, locations, and relevant heath data, will be accessed in a timely manner and collected by AI systems for calculation, analysis, and notification. Public opt-in and well-founded trust in the digital system, its implementation, and the governance framework are therefore essential factors regarding ethical issues at the organizational and societal levels for infectious disease surveillance, which could enable the acceptability and effectiveness of the system.

Even with optimal technical standards to maximally reduce the risks and consequences of data misuse, data safety, security, and integrity cannot be guaranteed. The role of AI-augmented infectious disease surveillance might only be supplementary for public health, while ethical issues are carefully observed. One of the most important challenges facing AI is to design and develop appropriate methods to deidentify personal information and protect privacy, yet a greater risk of false positive and false negative notifications exists with higher-level deidentified data [33].

Moreover, well-founded trust and confidence vary in different countries and between individuals. People in democratic countries tended to distrust AI-augmented surveillance systems by challenging them when personal information is reported to health authorities, often without appropriate informed consent [3]. In contrast, Chinese citizens expressed their trust in the
Chinese government's response to COVID-19, which they felt had been highly successful in controlling the spread of the virus through the use of mobile phone data combined with intensive testing and restriction programs [44]. Although there is no unified standard to establish trust, the need for effective, transparent, accountable, and independent oversight is very important.

\section{Generation of an Ethical Framework and Global Governance Structures}

Digital standards and guidelines for developing and evaluating the performance of infectious disease surveillance alone are insufficient. The scope of the ethical framework in Textbox 1 needs to be expanded globally. Cross-national and national governance structures; institutional systems with regulatory, medical, ethical, and legal frameworks; and benchmarking standards have essential roles to play in the development and deployment of these new health technology systems. However, this review identified the urgent need for an ethical framework to underscore all AI-augmented infectious disease surveillance systems $[18,19,30]$. Considering the rapid development of global trade supply chains, mass gatherings, and international travel, World Health Organization's International Health Regulations in 2005 [45] outlined the cross-border implications of a pandemic response and provided a framework for sharing, monitoring, and evaluating information from the sources of infections [37]. In response to a pandemic emergency, cross-border sharing of personal health data is essential for tracing infectious disease patients and their contacts. At the same time, cross-border sharing further raises the heightened and unique risk for individual privacy and security breaches. In turn, a spectrum of actions regarding ethical, political, and legal implications must be framed within strict safeguards and needs to be mandated globally [37].

\section{Implications}

A systematic medical, ethical, and legal framework is necessary for governance of AI-augmented infectious disease surveillance and the protection of personal privacy and data integrity. Public health systems should maximally increase the social awareness of AI surveillance and BDA for infectious diseases, and implement new technologies for infectious disease surveillance in a more person-centered and humane manner. Future research needs to focus on the setting up and implementation of an AI-augmented infectious disease surveillance system underscored by an ethical framework based on universal human rights. Decision makers should take into account varying and diverse population needs, sociocultural status, and regulatory and legal governance in order to promote trust building between end users, including infectious disease patients, doctors, and AI system implementers. This systematic review is intended to contribute to the development of a more comprehensive and concrete ethical framework for AI-augmented infectious disease surveillance, which will enable it to ultimately maximize public health responsiveness synergized within an ethical context.

\section{Conflicts of Interest}

None declared. 


\section{Multimedia Appendix 1}

PRISMA (Preferred Reporting Items for Systematic Reviews and Meta-Analyses) checklist. [DOCX File, $31 \mathrm{~KB}-$ Multimedia Appendix 1]

\section{References}

1. Vlieg WL, Fanoy EB, van Asten L, Liu X, Yang J, Pilot E, et al. Comparing national infectious disease surveillance systems: China and the Netherlands. BMC Public Health 2017 May 08;17(1):415 [FREE Full text] [doi: 10.1186/s12889-017-4319-3] [Medline: 28482830]

2. Garattini C, Raffle J, Aisyah DN, Sartain F, Kozlakidis Z. Big data analytics, infectious diseases and associated ethical impacts. Philos Technol 2019;32(1):69-85 [FREE Full text] [doi: 10.1007/s13347-017-0278-y] [Medline: $\underline{31024785]}$

3. Parker MJ, Fraser C, Abeler-Dörner L, Bonsall D. Ethics of instantaneous contact tracing using mobile phone apps in the control of the COVID-19 pandemic. J Med Ethics 2020 Jul 04;46(7):427-431 [FREE Full text] [doi:

10.1136/medethics-2020-106314] [Medline: $\underline{32366705]}$

4. McCarthy M. Slow response contributed to scale of west African Ebola epidemic, CDC concludes. BMJ 2016 Jul 08;354:i3814. [doi: 10.1136/bmj.i3814] [Medline: 27401324]

5. Temko A, Marnane W, Boylan G, Lightbody G. Clinical implementation of a neonatal seizure detection algorithm. Decis Support Syst 2015 Mar;70:86-96 [FREE Full text] [doi: 10.1016/j.dss.2014.12.006] [Medline: 25892834]

6. Gilbert GL, Degeling C, Johnson J. Communicable disease surveillance ethics in the age of big data and new technology. Asian Bioeth Rev 2019 Jun 10;11(2):173-187 [FREE Full text] [doi: 10.1007/s41649-019-00087-1] [Medline: 32218872]

7. Singapore personal data hack hits $1.5 \mathrm{~m}$, health authority says. BBC. 2018. URL: https://www.bbc.com/news/ world-asia-44900507 [accessed 2021-04-30]

8. Tanner A. How Your Medical Data Fuels a Hidden Multi-Billion Dollar Industry. Time. 2017. URL: https://time.com/ 4588104/medical-data-industry/ [accessed 2021-04-20]

9. Lazer D, Kennedy R, King G, Vespignani A. Big data. The parable of Google Flu: traps in big data analysis. Science 2014 Mar 14;343(6176):1203-1205. [doi: 10.1126/science.1248506] [Medline: 24626916]

10. Vanessa T, Culnane C, Rubinstein B. The simple process of re-identifying patients in public health records. Pursuit. 2017. URL: https://pursuit.unimelb.edu.au/articles/the-simple-process-of-re-identifying-patients-in-public-health-records [accessed 2021-03-30]

11. Floridi L, Taddeo M. What is data ethics? Philos Trans A Math Phys Eng Sci 2016 Dec 28;374(2083):20160360 [FREE Full text] [doi: 10.1098/rsta.2016.0360] [Medline: 28336805]

12. Salerno J, Knoppers BM, Lee LM, Hlaing WM, Goodman KW. Ethics, big data and computing in epidemiology and public health. Ann Epidemiol 2017 May;27(5):297-301. [doi: 10.1016/j.annepidem.2017.05.002] [Medline: 28595734]

13. Whittemore R, Knafl K. The integrative review: updated methodology. J Adv Nurs 2005 Dec;52(5):546-553. [doi: 10.1111/j.1365-2648.2005.03621.x] [Medline: 16268861]

14. Hong QN, Fàbregues S, Bartlett G, Boardman F, Cargo M, Dagenais P, et al. The Mixed Methods Appraisal Tool (MMAT) version 2018 for information professionals and researchers. EFI 2018 Dec 18;34(4):285-291. [doi: 10.3233/efi-180221]

15. Asadi SI, Breidbach CF, Davern M, Shanks G. Ethical implications of big data analytics. 2016 Presented at: European Conference on Information Systems (ECIS); June 12-15, 2016; Istanbul, Turkey URL: https://aisel.aisnet.org/ecis2016 rip/ $\underline{24 /}$

16. Someh I, Davern M, Breidbach CF, Shanks G. Ethical issues in big data analytics: a stakeholder perspective. CAIS 2019:718-747. [doi: 10.17705/1cais.04434]

17. Degeling C, Carter SM, van Oijen AM, McAnulty J, Sintchenko V, Braunack-Mayer A, et al. Community perspectives on the benefits and risks of technologically enhanced communicable disease surveillance systems: a report on four community juries. BMC Med Ethics 2020 Apr 25;21(1):31 [FREE Full text] [doi: 10.1186/s12910-020-00474-6] [Medline: 32334597]

18. Kim E, Chung J. Korean mothers' morality in the wake of COVID-19 contact-tracing surveillance. Soc Sci Med 2021 Feb;270:113673 [FREE Full text] [doi: 10.1016/j.socscimed.2021.113673] [Medline: 33453628]

19. Degeling C, Chen G, Gilbert GL, Brookes V, Thai T, Wilson A, et al. Changes in public preferences for technologically enhanced surveillance following the COVID-19 pandemic: a discrete choice experiment. BMJ Open 2020 Nov 18;10(11):e041592 [FREE Full text] [doi: 10.1136/bmjopen-2020-041592] [Medline: 33208337]

20. Thomas R, Michaleff ZA, Greenwood H, Abukmail E, Glasziou P. Concerns and misconceptions about the Australian government's COVIDSafe app: cross-sectional survey study. JMIR Public Health Surveill 2020 Nov 04;6(4):e23081 [FREE Full text] [doi: 10.2196/23081] [Medline: $\underline{33048826}$ ]

21. Degeling C, Johnson J, Gilbert GL. Perspectives of Australian policy-makers on the potential benefits and risks of technologically enhanced communicable disease surveillance - a modified Delphi survey. Health Res Policy Syst 2019 Apr 04;17(1):35 [FREE Full text] [doi: 10.1186/s12961-019-0440-3] [Medline: 30947721]

22. Sweeney Y. Tracking the debate on COVID-19 surveillance tools. Nat Mach Intell 2020 Jun 16;2(6):301-304. [doi: 10.1038/s42256-020-0194-1] 
23. Schwalbe N, Wahl B. Artificial intelligence and the future of global health. Lancet 2020 May 16;395(10236):1579-1586 [FREE Full text] [doi: 10.1016/S0140-6736(20)30226-9] [Medline: 32416782]

24. Katapally TR. A global digital citizen science policy to tackle pandemics like COVID-19. J Med Internet Res 2020 May 26;22(5):e19357 [FREE Full text] [doi: 10.2196/19357] [Medline: 32408267]

25. Mbunge E. Integrating emerging technologies into COVID-19 contact tracing: Opportunities, challenges and pitfalls. Diabetes Metab Syndr 2020;14(6):1631-1636 [FREE Full text] [doi: 10.1016/j.dsx.2020.08.029] [Medline: $\underline{32892060]}$

26. Garg S, Bhatnagar N, Gangadharan N. A case for participatory disease surveillance of the COVID-19 pandemic in India. JMIR Public Health Surveill 2020 Apr 16;6(2):e18795 [FREE Full text] [doi: 10.2196/18795] [Medline: $\underline{32287038]}$

27. Denecke K. An ethical assessment model for digital disease detection technologies. Life Sci Soc Policy 2017 Sep 20;13(1):16 [FREE Full text] [doi: 10.1186/s40504-017-0062-x] [Medline: 28929347]

28. Kostkova P. Disease surveillance data sharing for public health: the next ethical frontiers. Life Sci Soc Policy 2018 Jul 04;14(1):16 [FREE Full text] [doi: 10.1186/s40504-018-0078-x] [Medline: 29971516]

29. Vayena E, Salathé M, Madoff LC, Brownstein JS. Ethical challenges of big data in public health. PLoS Comput Biol 2015 Feb;11(2):e1003904 [FREE Full text] [doi: 10.1371/journal.pcbi.1003904] [Medline: 25664461]

30. de Jong BC, Gaye BM, Luyten J, van Buitenen B, André E, Meehan CJ, et al. Ethical considerations for movement mapping to identify disease transmission hotspots. Emerg Infect Dis 2019 Jul;25(7) [FREE Full text] [doi: 10.3201/eid2507.181421] [Medline: $\underline{31211938]}$

31. Kind C. Exit through the App Store? Patterns (N Y) 2020 Jun 12;1(3):100054 [FREE Full text] [doi: 10.1016/j.patter.2020.100054] [Medline: 32548597 ]

32. Park S, Choi GJ, Ko H. Information technology-based tracing strategy in response to COVID-19 in South Korea-privacy controversies. JAMA 2020 Jun 02;323(21):2129-2130. [doi: 10.1001/jama.2020.6602] [Medline: 32324202]

33. Fraser C, Abeler-Dorner L, Ferretti L, Parker M, Kendall M, Bonsall D. Digital contact tracing: comparing the capabilities of centralised and decentralised data architectures to effectively suppress the COVID-19 epidemic whilst maximising freedom of movement and maintaining privacy. University of Oxford. 2020. URL: https://tinyurl.com/y4bjggke [accessed 2021-09-30]

34. Cho H, Ippolito D, Yu YW. Contact Tracing Mobile Apps for COVID-19: Privacy Considerations and Related Trade-offs. arXiv. URL: https://arxiv.org/abs/2003.11511 [accessed 2021-09-30]

35. Klenk M, Duijf H. Ethics of digital contact tracing and COVID-19: who is (not) free to go? Ethics Inf Technol 2020 Aug 24:1-9 [FREE Full text] [doi: 10.1007/s10676-020-09544-0] [Medline: $\underline{32863740]}$

36. de Montjoye YA, Houssiau F, Gadotti A, Guepin F. Evaluating COVID-19 contact tracing apps? Here are 8 privacy questions we think you should ask. Computational Privacy Group. 2020. URL: https://cpg.doc.ic.ac.uk/blog/ evaluating-contact-tracing-apps-here-are-8-privacy-questions-we-think-you-should-ask/ [accessed 2021-02-20]

37. Bernier C, Fong L, Banks TM. Pandemics in a Connected World: Integrating Privacy with Public Health Surveillance. University of New Brunswick Law Journal. 2015. URL: https://journals.lib.unb.ca/index.php/unblj/article/view/29090 [accessed 2021-09-30]

38. Ienca M, Vayena E. On the responsible use of digital data to tackle the COVID-19 pandemic. Nat Med 2020 Apr;26(4):463-464 [FREE Full text] [doi: 10.1038/s41591-020-0832-5] [Medline: 32284619]

39. Yasaka TM, Lehrich BM, Sahyouni R. Peer-to-peer contact tracing: development of a privacy-preserving smartphone app. JMIR Mhealth Uhealth 2020 Apr 07;8(4):e18936 [FREE Full text] [doi: 10.2196/18936] [Medline: $\underline{32240973]}$

40. Barbieri C, Darnis JP. Technology: An Exit Strategy for COVID-19? Istituto Affari Internazionali. 2020. URL: https:/ /www.iai.it/en/pubblicazioni/technology-exit-strategy-covid-19 [accessed 2021-09-30]

41. Chan J, Foster D, Gollakota S, Horvitz E, Jaeger J, Kakade S, et al. PACT: Privacy Sensitive Protocols and Mechanisms for Mobile Contact Tracing. arXiv. 2020. URL: https://arxiv.org/abs/2004.03544 [accessed 2021-09-30]

42. Lewis P. Trust in the government is rising - but will Australians accept the coronavirus tracing app? The Guardian. 2020. URL: https://www.theguardian.com/australia-news/commentisfree/2020/apr/20/ trust-in-the-government-is-rising-but-will-australians-accept-the-coronavirus-tracing-app [accessed 2021-09-30]

43. WHO Coronavirus (COVID-19) Dashboard. World Health Organization. 2021. URL: https://covid19.who.int/ [accessed 2021-02-20]

44. COVID-19 boosts Chinese citizens' trust in their government: survey. Xinhua. 2021. URL: http://www.china.org.cn/world/ 2021-05/14/content 77498248.htm [accessed 2021-07-11]

45. International Health Regulations. World Health Organization. URL: https://www.who.int/health-topics/ international-health-regulations\#tab=tab_1 [accessed 2021-05-20]

\section{Abbreviations}

AI: artificial intelligence

BDA: big data analytics

EHR: electronic health record

ML: machine learning 


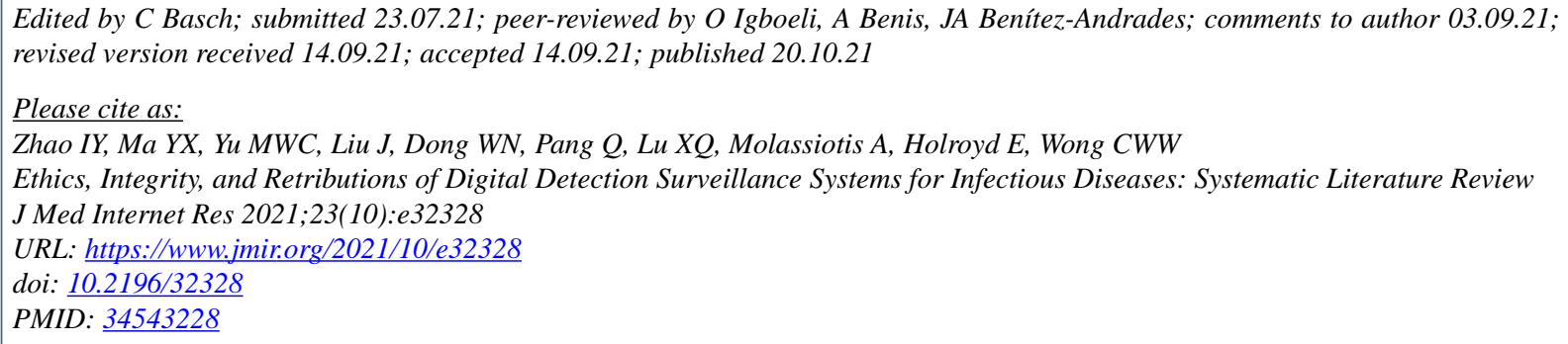

CIvy Y Zhao, Ye Xuan Ma, Man Wai Cecilia Yu, Jia Liu, Wei Nan Dong, Qin Pang, Xiao Qin Lu, Alex Molassiotis, Eleanor Holroyd, Chi Wai William Wong. Originally published in the Journal of Medical Internet Research (https://www.jmir.org), 20.10.2021. This is an open-access article distributed under the terms of the Creative Commons Attribution License (https://creativecommons.org/licenses/by/4.0/), which permits unrestricted use, distribution, and reproduction in any medium, provided the original work, first published in the Journal of Medical Internet Research, is properly cited. The complete bibliographic information, a link to the original publication on https://www.jmir.org/, as well as this copyright and license information must be included. 